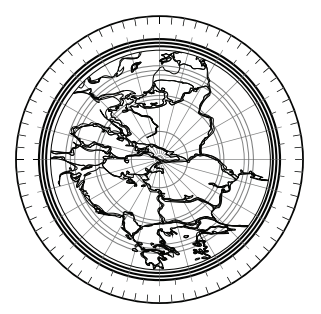

Sprawy Narodowościowe: Seria nowa, 2021(53), Article 2570

\title{
Ways of Othering: Literary Image of Russians in Habsburg Lviv
}

DOI: https://doi.org/10.11649/sn.2570

\author{
Katarzyna Kotyńska \\ Institute of Slavic Studies, Polish Academy of Sciences \\ https://orcid.org/0000-0002-5242-1902 \\ e-mail: katarzyna.kotynska@ispan.waw.pl
}

\begin{abstract}
The popular image of multicultural Lviv/Lwów in general, and under Habsburg rule in particular, usually excludes Russians from the group of genuine city dwellers. The main aim of this paper is to analyse the few portrayals of Russians in literary texts relating to the period of WWI. I compare Polish strategies of othering Russians as barbarians and an insidious element, prevalent in the literature for young readers of the 1920s, with the tendency of some Ukrainian authors to create a more nuanced image in the mass literature of the 2010s. The analysis of ways of othering Russians in the two identified groups of literary texts considers the geopolitical and national identity issues underpinning these trends.
\end{abstract}

Keywords: Lwów; Lviv; stereotype; othering; Ukrainian literature; Polish literature

This article focuses on the widely declared image of Lviv as a genuinely multicultural city, where each nation and ethnicity has a safe and friendly place for themselves

This work was supported by the Polish Ministry of Education and Science.

No competing interests have been declared.

Publisher: Institute of Slavic Studies, Polish Academy of Sciences.

This is an Open Access article distributed under the terms of the Creative Commons Attribution 3.0 PL License (creativecommons.org/licenses/by/3.0/pl/), which permits redistribution, commercial and non-commercial, provided that the article is properly cited. (c) The Author 2021. 
(e.g. Czaplicka, 2000; Kotyńska, 2015; Vozniak, 2009). However, in the commonly accepted Polish and Ukrainian multicultural image of Lwów/Lviv, ${ }^{1}$ until quite recently one ethnic group was excluded from this declared equality in diversity: Russians and, in a broader sense, Russian-speaking residents. Despite their presence in the city, transient in the interwar period and becoming a constant feature ever since 1945, this group was rarely presented in literary texts as genuine residents of Lwów/Lviv (Kotyns'ka, 2020).

In this article, I intend to go back in time and to establish the framework and patterns of literary representations of Russians passing through Lviv before they became a constant part of the city's life in the first decades of the twentieth century. There are not many Polish or Ukrainian texts which refer to Russians in Lviv during this period; still, they provide sufficient material to allow the analysis of ways of othering the representatives of powerful neighbouring culture, a feature which remained important for national self-identification in both cases: Polish after WWI and Ukrainian in the 2010s. I focus on two groups of texts. They are distant from each other in terms of publication dates, yet, in a way, they are the first of their kind and they pursue the same goal. In the 1920s, Poland was focused on reinforcing its newly regained independence. After the Polish-Soviet war of 1919-1920, the Russian-speaking soldier, as a representative of the alien communist regime, was a good candidate for a figure of contrast in the processes of creating a coherent self-image of Poles in their new state.

The Ukrainian situation in the second half of 2010s showed significant similarities to that described above, yet not without some simplifications that I propose in order to compare these texts with their Polish counterparts. Russia's annexation of the Crimea and the ongoing War in the Donbas reactivated discussions on national identity and state loyalty in Ukraine, where the geopolitical vector had never been clearly chosen. Thus, the story of Russian interlopers in Lviv at the beginning of the twentieth century served as a mirror for contemporary dilemmas.

In both cases, Russian literary characters are used to strengthen the image of one's own nation as a coherent community by showing the overwhelming difference between "Us" (Poles or Ukrainians, respectively) and "Them" (Russians). I refer to the theory of the nation as an invented, imagined community (Anderson, 1997; Gellner, 2009; Kłoskowska, 2005). This presupposes the existence of the image frame - the neighbours. Drawing the boundary between the image ("Us") and the frame ("Them") requires some effort when the neighbouring culture is perceived as stronger or dominant. Furthermore, in both cases Russian characters appear in literary texts intended not for literary gourmets or readers with refined tastes, but for a mass audience, even if different in each case: Polish children who were to be patriotically educated, and adult Ukrainian fans of crime fiction.

1 In this article, I acknowledge the multicultural character of the city, which is embodied in the variety of its names: Lemberg (German), Lwów (Polish), Lviv (Ukrainian). When speaking about the city in general, I use its current Ukrainian name: Lviv. When referring to the reality depicted in the discussed novels or elements of national discourse, I use the relevant version of the name: Lwów, Lviv or Lemberg. 
As for the Polish literary works considered here, they are stories for young readers published shortly after the end of WWI. Literature for young readers was the first to use the figure of the Russian soldier to contrast the "good" Poles with the "bad" Others. During WWI, the Russian Empire held control of Lviv for four months in 1914 and again for another nine months in 1916. Here, I focus on three texts. The first one is "Lulu" by Helena Zakrzewska, a short story about an orphaned boy of this name. It was published as early as in 1919 in a book entitled Dzieci Lwowa [The Children of Lwów], along with "W obronie swego gniazda" [In Defence of Their Nest]. In the latter, Zakrzewska describes the young defenders of Lwów (the so called "Lwów Eaglets"), which was of key importance for the formation of Polish patriotism in the interwar period. The story of the defence of the city, mainly by volunteers, young people and women, became an educational model in the first years of the reborn Poland (Wierzejska, 2016). In fact, the popularity of "W obronie swego gniazda" overshadowed "Lulu" with its visceral representation of Russians - the story was quickly recognised as a canonical depiction of Polish patriotic devotion evident during the Polish-Ukrainian battle for Lviv (November 1918). It was released separately, had many editions and became a required reading for all schoolchildren in interwar Poland.

The second Polish text in focus is Bohaterski miś [The Heroic Teddy Bear] by Bronisława Ostrowska, a popular patriotic tale with anthropomorphised toys and household goods, first published also in 1919. The final Polish work considered here is a novel by Zakrzewska entitled Biate róże [White Roses], set somewhat later, during the PolishSoviet war of 1919-1921, when Lwów was less of a focal point in terms of military actions. Still, this book, first published in 1924, offers an interesting background to compare and contrast some changes in the representations of Russians in Polish interwar literature for young readers.

It is worth pointing out that all those works are still present in Polish bookshops: after 1989, Dzieci Lwowa was re-released in 1990, 2004, 2016 and 2020 by three different publishing houses; Bohaterski miś - in 2011, and from 2016 it is available as an open access e-book; Białe róże - in 1990 and 2014. Moreover, in Polish conservative circles, continuing the ideological line of the interwar National Democracy party of Roman Dmowski, those texts are still considered foundational for patriotic education - see for example recommendations in Nadolna-Tłuczykont's study on books banned by the communist authorities (Nadolna-Ttuczykont, 2013), or in the right-wing online bookshop Multibook (www.multibook.pl, retrieved 02.09.2021).

Still, the image of Russian intruders does not appear in Polish mass literature about Lviv later on. Thus, the first question is why and for what purpose the Polish authors created an image of the Russian intruder in Lviv just after WWI?

In contrast, considering Ukrainian literature, I focus on a series of highly popular historical detective novels by Andrii Kokotiukha, published since 2015. The first volume is set in 1905, and Russians are represented by terrorists from Saint Petersburg arriving 
in Lviv on a mission. The fifth volume of the series is set in 1916, and the actual presence of Russian military troops in the city is crucial for the development of the plot. Here the above question needs to be somewhat adjusted: why and for what purpose does a Ukrainian writer of the twenty-first century create the first Ukrainian literary images of Russian intruders in Austro-Hungarian Lviv?

Despite the difference of the projected literary audience (Polish children vs Ukrainian adults), both groups of texts, each representing popular literature in their respective ways, feature the first coherent image of Russian behaviour and actions in Lviv in the 1900s and 1910s. For the time being, I have not found any Polish literary texts for adults on this topic, no matter when published. The same applies to Ukrainian literary texts: neither I nor Ukrainian literary critics, who emphasise the novelty of Kokotiukha's series, have found any popular Ukrainian literary text on this topic published before his series appeared.

The Polish and Ukrainian works analysed below fall into the category of popular literature, intended for mass reader. Texts of this kind operate with commonly understood categories and images; they feed stereotypes but they can also modify them by way of strengthening, weakening or activating. One objective of this literature is to consolidate recipients around common values. Furthermore, popular texts mirror not only the reality of a certain period, but also the state of mind of their authors, with their social commitment and potential didactic goals (Kajtoch, 2015). Anthropological analysis of such texts (e.g. Burszta, 2004; Czubaj, 2010) reveals the key design elements of the image of the world and the ways of differentiating "Ours" from "Others" in a constant struggle to strengthen the sense of national identity in a period of historical turmoil.

The aim of my analysis is to identify the roles assigned in those stories to Russian characters connected with historical events in the period of 1914-1916. I also examine the strategies of othering Russians used by Polish and Ukrainian authors, respectively.

\section{Poland, the 1920s}

In the Polish collective memory, the Russian intrusion into Lwów during WWI is remembered as a relatively insignificant aspect of the Polish war experience. Considering the first half of the twentieth century, it is the Polish-Ukrainian conflict of November 1918 that overshadows any other historical event related to the city (Wierzejska, 2016). In the turbulent times following the re-establishment of the Polish state after 1918, literature for young readers remained an important resource in shaping the new patriotic attitudes and reinforcing a sense of Polishness among compatriots, as shown in detail in the studies by Jagoda Wierzejska and Anna Maria Krajewska (Krajewska, 2009; Wierzejska, 2016). As a result, in these texts Russians as "Others", representatives of a powerful geopolitical rival, served as one of the templates for the "non-us" (Gellner, 2009), in this case: "non-Poles". It is worth mentioning that, in general, interwar Polish literature on 
Lwów shows the Polish residents of the city as positive heroes, while the Ukrainian ones - mostly as antiheroes. Sometimes it also evokes Armenians as an exotic element of the social landscape, or Jews as obvious but at the same time somewhat suspicious neighbours. Russians are not considered fellow residents of the city, their presence is not a topic of literary interest.

The entry of Russian troops into Lviv in 1914 was viewed by Polish citizens mostly as a temporary fluctuation in the tides of war (cf. L'viv pislia rosiìs'koho vtorhnennia, 2003²). In contrast, the occupation of 1916 resulted in a more dramatic and tangible clash of civilisations. The traditional values of the Polish middle- and upper-class city dwellers clashed with a foreign ethos, the Russian army, which they perceived as incomprehensible.

Behind the general division into two distinct groups: civilised, western Poles versus barbarian, eastern Russians, there is yet another clear distinction: between the Russian aristocracy and simple foot soldiers. The ordinary infantry soldiers are described, both by Ostrowska and Zakrzewska, as victims of political plots. In those texts, representatives of different social strata are assessed differently: the officers-aristocrats make decisions and, as such, take main responsibility for the cruelty of the ongoing conflict. Their barbarous attitude is perceived as a result of their own civilisational choice. The simple soldiers with their lack of manners are, in a sense, only victims of great power politics. Teddy Bear from Ostrowska's book recounts:

I hear him [the orderly Grishka] complaining to himself:

"They drag people around the world, [make them] fight other people. Bad about this country. Oh, if only these sobaki ["dogs" in transliterated Russian] would let me go, home", he sighs heavily.

This, however, is beyond my bearlike understanding.

So he is here not out of his own good will? But then...

Apparently the word "enemy" is not that simple. (Ostrowska, 1988, p. 14)

And again, when the Russian general in the same book requisitions the apartment of his choice, without paying any regard to the rights of its legitimate owners, all of the household goods are suitably disgusted by his uncouth behaviour and prepare to organise a "household goods strike" (Ostrowska, 1988, p. 14). In the meantime, when the general's orderly, Grishka, suffers as a result of their malice while performing his duties, the titular Teddy Bear shows some sympathy for him (Ostrowska, 1988, p. 25).

There are two other features typical of the 1920s which are worthy of further discussion. The first one is that Zakrzewska in Białe róże identifies the zealous Bolsheviks as

\footnotetext{
2 For the time being, I have no information about the Polish source of this translation.

3 If not indicated otherwise, the original texts were translated into English by the author of this article.

"Słyszę go, jak wymyśla sam do siebie:

- Ciągają człowieka po świecie, cudze wojować. Złe w tym kraju. [...] Ot, puściliby, sobaki, do domu - wzdycha ciężko.

To jednak przechodzi już całkiem moje niedźwiedzie zrozumienie.

Więc on nie z dobrej woli? Ale w takim razie...

Nie takie to widać proste słowo - wróg".
} 
being of Jewish ethnicity. In her novel, the worst characters are the female Jewish Bolshevik commissars. The power accumulated in the hands of these characters is perceived as a symbol of breaking all the rules of the so-called "civilised" society, with its clear traditions, social and gender roles, and social strata. Such a commissar would thus trample upon all the boundaries of peaceful, orderly life as it was before WWI.

The second feature is the method of description applied when presenting enemy troops, both those of the imperial Russian army (1914-1916) and the Soviet Russian army (1919-1921). In the majority of cases, they are not referred to as "Russians". For example, in "Lulu" most of the time the main dilemma and danger is represented by the war itself. Here the name "Russians" is quite neutral in this context: it applies to civilians (doctors, nurses, etc.) as well as to the soldiers following orders. This is also the case of Siemion, Lulu's temporary guardian, "a man of great stature, with a broad, good-natured face, covered in a linen-like beard that reached all the way up to his blue eyes" (Zakrzewska, 2004, p. 13). ${ }^{4}$

When it comes to war crimes, it is not the "Russian soldiers" who are guilty. The criminal and rogue elements are consistently referenced by Zakrzewska as "Cossacks" or "Tatars". This seems to appeal to the Polish collective imagination and collective memory, evoking the cruelty of the Tatar invasions and the Cossack uprisings of the past (cf. Bohun, 2006). The history of the Polish-Russian wars or inter-ethnic relations during the eighteenth and nineteenth centuries, despite the numerous crushing defeats and reprisals, does not seem to provide an emotive enough background. In other words, because of historical associations calling a cut-throat "Cossack" or "Tatar" sounds much scarier than "Russian".

The choice thus taken leads to the uncertain and often troublesome ground of Polish-Ukrainian relations. For the Polish reader, the use of the term "Cossacks" strengthens the negative anti-Ukrainian stereotypes, especially considering the whole image of the Ukrainian nation as represented in the interwar patriotic youth literature about Lviv (Kotyńska, 2015, pp. 49-59; Krajewska, 2009, pp. 241-260). The Ukrainians were seen as fellow citizens only as long as they agreed to Polish cultural and political supremacy; and, still, the pride of place was occupied by the stories of how the brave Polish child soldiers, the "Lwów Eaglets", outwitted the doltish Ukrainians.

A final note concerning the Polish texts is that of the endeavour to trace the roots of certain clichés. As mentioned above, it was in the early 1920s that the famous stories emerged about the barbaric and uncouth Russians encountering Western civilisation. There

\footnotetext{
4 "Chłop olbrzymi, z szeroką, dobroduszną twarzą, zarosłą Inianą brodą aż po niebieskie oczy".

5 Drunk "Cossacks" from "the wild sotnia" (i.e. military unit) kill Lulu's mother and nanny (Zakrzewska, 2004, pp. 10, 39): "The Russian troops had already left the city, only the rear guard, made up of wild Cossacks, remained. Despite strict orders, robberies and unrest began. Especially in the suburbs, drunk soldiers raged along with the bandits and thugs who had come out of their burrows" ("Wojska rosyjskie wyszły już z miasta, została tylko straż tylna, złożona z dzikich Kozaków. Mimo surowych rozkazów zaczęły się rabunki i niepokoje. Szczególnie na przedmieściach rozhulali się pijani żołnierze do spółki z bandytami i rzezimieszkami, którzy powyłazili ze swoich nor"). So we have a clear separation here: there are "Russian troops" considered to be enemies, but acceptable ones, in contrast to "wild Cossacks", accused of all crimes - even if in the same sentence the author informs that they are part of the very same army.
} 
is a canonical story about a Russian (Soviet) soldier wearing several confiscated or stolen watches on each arm. In the narrative of Białe róże I found the earliest known occurrence of the following typical scene: a Russian soldier demands a watch, shouting "Daval chasy!" ("Give me the watch!") (Zakrzewska, 1990, p. 78). Another reference to inherent Russian oafishness can be noted early in the same novel: a soldier discovers toothpaste for the first time in his life and, fascinated, proceeds to eat the whole tube, much to the excitement and amusement of a Polish girl observing the scene (Zakrzewska, 1990, p. 88).

As mentioned above, in Polish literature there are very few portrayals of Russians in Habsburg Lemberg during the period around WWI. Russians were not given much attention by Polish authors because their political activities before WWI were viewed as primarily concerning Ukrainians/Ruthenians, ${ }^{6}$ not Poles. The actual Russian presence in Lviv during the war proved to be relatively short and, apparently, left no clear emotional traces in the Polish collective memory. From the perspective of an ordinary citizen of Lviv, the Ukrainian-Polish war of 1918 was far more important, which was reflected in the number of literary texts on this topic (cf. Wierzejska, 2016). Moreover, considering the literary figure of the Russian (Soviet) soldier, it was Poland's struggle to establish its eastern frontier - with its culmination at the Battle of Warsaw (August 1920) and subsequent retreat of the Soviet Red Army - that came to overshadow all other events of the period, as shown in Krajewska's study (Krajewska, 2009, pp. 265-421).

\section{Ukraine, the 2010s}

In the last ten years, Ukrainian literature and culture in Lviv have been keen on exploring the topics omitted or neglected by Polish authors when writing of the city and its inhabitants. For example, this has been the case of the Jewish past or the biographies of Lviv's many Czech and Italian architects, carefully collected for example in the Internet resources of the Centre for Urban History as part of the project "Lviv Interactive" (https:// lia.lvivcenter.org/, retrieved 7.09.2021). Recently, the growing interest in Lviv's other nationalities has extended to the Russian city dwellers and temporary residents. This trend has also covered the presence of Russian armed forces during WWI, as well as the political activities undertaken in Lviv before the war by the subjects of Russian Tsar.

To further explore this new wave, I focus on the highly popular series of seven historical detective novels by Andrii Kokotiukha, released in 2014-2017. The plot concerns the adventures of a young Ukrainian lawyer, Klym Koshovyı̌, forced to move from Kiev to Lviv due to political persecutions. The novels are set in the years 1905-1918, and here I will discuss two volumes of the series: the first, set in 1905, and the fifth, set in 1916.

\footnotetext{
6 In the Austro-Hungarian Empire, up to 1918, the term "Ruthenians" was an official exonym for the entire East
} Slavic population within the borders of the state, and was often used by Polish authors in relation to the Ukrainians. 
The first volume, The Lawyer from Lychakiv Street (Advokat z Lychakivs'koï), was originally published in 2015 (an English translation appeared in 2020). In this volume, the criminal mystery is directly related to the internal issues of the Ukrainian community in Galicia at the turn of the twentieth century, namely the rivalries among the various national factions: those loyal to the Habsburg monarchy, and the Moscophile faction, seeking the protection of the Russian Tsar. This is the first important difference in terms of the author's approach to the topic. For the aforementioned Polish authors, the problems caused by Moscophiles had virtually no relevance (Kokotiukha, 2016, p. 20). In Lviv, the Ukrainians, in that period often called "Ruthenians" (see note 6 above), were not considered a "real nation" by the vast majority of Polish authors at the time; the only issue of any interest was their potential threat to the Polish ambitions of independence. Meanwhile, Kokotiukha builds his plot focusing on the struggles amongst the Ukrainian factions, a key factor in social terms and in terms of the organisation of Galician Ukrainians in the period.

As the geopolitical background for the entire series is constructed on the principle of opposition between the (civilised) Habsburg Empire and the (wild) Russian Empire, the main protagonist, Klym Koshovy̆, is engaged in helping the Lviv police to defeat Russian terrorists who engage the local Moscophiles in the anti-Habsburg conspiracy. In my opinion, considering that the novel was published in 2015, the plot of "Russian intrigue" comes as an indirect reference to the international political situation on the eve of the Russian annexation of the Crimea in 2014. At the beginning of the conflict, some soldiers in unmarked green uniforms appeared in Simferopol. They described themselves as "self-defence forces", but were identified by Ukrainian volunteers as members of the Russian military (Reeves \& Wallace, 2015). In April 2014, Russian President Vladimir Putin finally confirmed the presence of the Russian army in Ukraine. Thus, in a broad sense, the Russian invasion of 2014 may be perceived as yet another stage of the centuries-long "Russian intrigue". Therefore, in his entertaining novel Kokotiukha decided to exploit the old clichés of the Russians as instigators and plotters in a situation where this would appeal directly to the current experiences of the readers. This is the second difference between the Polish and Ukrainian approaches to the subject.

For Ukrainians, the opposite compass points of Vienna and Moscow still form a part of everyday experience and remain present in the current geopolitical discussion. Should Ukraine lean to the West and join EU and NATO, or should it lean to the East and tighten its relationships with Russia? Contrarily, in the 1920s Poland the exhaustive Polish-Soviet war was vividly remembered. It enhanced the negative image of the Soviet Empire, equated in popular perception with the Russian state. Therefore, in the Polish political debates the pro-Eastern orientation was much weaker than in Ukraine at the beginning of the twenty-first century (Krajewska, 2009, pp. 63-96; Szwarc, 1990). In addition, cultural distance has always been much greater here than in the Ukrainian case.

The third difference concerns the very image of Russians - or, more precisely, members of the Russian army - as foreigners in Lviv. This is especially visible in the fifth 
part of Kokotiukha's series, entitled Kokhanka z Ploshchi Rynok [Mistress from the Main Square, 2016]. The action of this novel takes place in 1916 in Lviv, during the nine months of the Russian rule. The Russian authorities are represented by diverse, interesting characters who interact with the local community. The attitudes of these individuals vary depending on the circumstances. An example would be one Lieutenant Zubov, who, when furious, throws a stack of curses; however, he also knows how to be gentle, elegant and clever, as a good officer should be (Kokotiukha, 2016, pp. 6, 9, 28). ${ }^{7}$ The Russian terrorists from the first part of the series, as well as insidious Russian officers from the fifth part, are not only dangerous, they are also cunning and clever. They must not be underestimated: defeating this enemy requires great effort and skills. The outcome of these efforts is not a given and, therefore, the successful resolution of the criminal mystery brings real glory to the protagonist.

Kokotiukha shows the new rules under occupation as alien, stringent and sometimes cruel - yet still, they are new state rules. This does not change the fact that cooperation with the new authorities is far more morally ambiguous. When Koshovyǐ gets involved in the investigation conducted by the gendarmerie, his cooperation is purely professional. It is unavoidable for the reasons of self-preservation and, importantly, it does not bring harm to any of his compatriots. Nevertheless, when the Austrian authorities return to the city, his involvement in the investigation is considered to have been an act of collaboration with the enemy.

Even if the appearance, behaviour and some of the attitudes of the Russian newcomers are strange or difficult to understand for the dwellers of a western city like Lviv (i.e. shouting in public places, smoking odious makhorka instead of good quality tobacco), I claim that all this means that the Russians are perceived as just different. Of course, there is a line between Ukrainians as inhabitants of the West and Russians as inhabitants of East, but the overall view proposed by Kokotiukha is that of a clash of two civilisations with different sets of rules rather than the image of a savage invasion. There are no descriptions of Russian soldiers as wild, unpredictable men, aggressive by nature, as for example in Zakrzewska's "Lulu" (Zakrzewska, 2004, p. 10), and even no epithets like "wild" with reference to the Russians, present in Ostrowska's Bohaterski miś, where "a wild choir" of soldiers sings "a wild song" on their entry into Lwów (Ostrowska, 1988, p. 12).

Still, there are no doubts that Kokotiukha's sympathies lie on the side of the Western, Habsburg world, consistently described as "European", i.e. predictable and fair, and contrasted with the oppressive Russian Empire. For example, already at the very beginning of the first volume, when Klym Koshovyĭ, the protagonist, crosses the border between the Russian and Austro-Hungarian Empires, Russian border guards are described as stern

7 The same can be said about General Petr Barkhatov in Petro latsenko's L'vivs'ka saha [Lviv Saga] (IAtsenko, 2010). Of course, it is another widespread stereotypical image of the Russian officer, both Tsarist and, later on, Soviet. Still, this image provides the enemies with a bit of flesh and blood instead of depicting them as one-dimensional barbarians. 
clerks, and, in general, the atmosphere at the border crossing is hostile. The Austro-Hungarian guards, in contrast, behave professionally and kindly (Kokotiukha, 2015, pp. 20-23).

This view would be particularly important when it comes to the more nuanced portrayal of the Russian army. Kokotiukha places the action of his novel in the same historical period as Ostrowska and Zakrzewska, but his knowledge and experiences are different. Apart from the general clash of civilisations, he explores the issue of internal diversity of the army. Among the soldiers arriving in the city there were, of course, Russians, but there were also many Ukrainians from Central Ukraine, which was part of the Russian Empire at the time (Kokotiukha, 2016, p. 24). Until today, attempts to find a common language (in terms of culture, geopolitics, etc.) between Galician and Dnieper Ukraine form an important part of Ukrainian experience (cf. Riabczuk, 2004, 2015), and this is another aspect which was deemed irrelevant for the Polish authors and their narrative.

\section{Conclusions}

The two groups of texts, Polish and Ukrainian, that I have discussed above show three main similarities. First, their plots are set in Lviv, a city of considerable importance for the building of both Polish and Ukrainian national identities. Second, they are first and only to show the presence of Russians in the city in the first quarter of the twentieth century. Third, they are intended for a mass audience, even if their target audiences are different.

I was looking for the earliest literary images of Russians in Lviv because I am convinced that their weak presence in the contemporary multicultural image of the city (despite their actual presence there), which is the starting point of this article, results, among others, from old stereotypes and patterns of collective memory. The analysis of historical Polish novels for young readers helps to establish the ways of forming a widespread image of Russians in Lwów/Lviv as barbarians. It is also an opportunity to trace the roots of some stereotypical images reappearing in literary texts of the twentieth and twenty-first centuries. These images are present in both Polish and Ukrainian texts concerning Russians in Lwów/Lviv regardless of the period described, and, what is more, they are similar.

For both groups of texts discussed here, regardless of the hundred-year gap between them, Russians in Lwów/Lviv serve as a template of the "Other". It is one's own identity, either Polish or Ukrainian, which is in fact constructed in contrast to it. Still, the Ukrainian 2010s significantly differ from the Polish 1920s. Since the early 2000s, the presence of Russians and Russian speakers in Lviv has gradually become the subject of more and more detailed research (Kotyns'ka, 2020). The daily presence of Russians and Russian-speaking persons in Ukrainian social and political life gives much more varied background for creating the fictional conflict and the attitudes of the characters. Kokotiukha, an experienced craftsman, skilfully uses the nuances and earlier associations. 
At first sight, the ways of distinguishing between "Ours" and "Others", the mockery and stereotyping of the "barbarians", seem to be similar in Polish and Ukrainian works under consideration, regardless of the lapse of almost a hundred years between their publication. The proximity of their Russian neighbours had, in a way, similar importance for Poles in the 1920s and for Ukrainians in the 2010s. In search of new, more precise definitions of their own identity, the Polish and Ukrainian authors explored resemblances and dissimilarities between their mode of life and the image of their powerful neighbour. Still, in the case of Polish texts, Russians were rather simply depicted as savages, grotesque representatives of eastern sub-standard civilisation, in opposition to honourable, honest Poles. This image served to strengthen Polish patriotism at a fragile geopolitical time.

The Ukrainian interpretation, proposed in the 2010s, many years after WWI and in different socio-political circumstances, has proved to be more nuanced. The plots of insidious Russian intrusion (The Lawyer from Lychakiv Street, set in 1905) and Russian aggression (Kokhanka z Ploshchi Rynok, set in 1916) make strong reference to the issues of the current Ukrainian-Russian relations. In my opinion, it was the ongoing conflict in the Crimea and eastern Ukraine that led the author to explore the plot of Russian intrigue in historical crime fiction, of course, with the victorious Ukrainians. The general idea of strengthening the national self-consciousness is still there, as in the case of the Polish works, but, in addition, the reader is invited to reflect on internal differentiation of Ukrainian people: then, at the beginning of the twentieth century, and per analogiam today, a hundred years later.

Kokotiukha depicts the former victory over the Russians as a form of comfort to his contemporary readers, but there is a very important nuance here: that victory was made possible thanks to the combination of the Western order (Lviv police as part of the Austro-Hungarian Empire) and in-depth knowledge of the Eastern enemy (Koshovyǐ is a former subject of the Tsar). In this way Kokotiukha supports the modern identity project: the internal diversity is the real Ukrainian strength. I consider it to be an example of modern antropologisation of mass literature, described as a noticeable feature by Wojciech Burszta (Burszta, 2004) and Mariusz Czubaj (Czubaj, 2010), where a story attracts the reader not only with an entertaining criminal mystery but also with an interpretation of the social and political backdrop to the reality.

\section{References}

Anderson, B. (1997). Wspólnoty wyobrażone: Rozważania o źródłach i rozprzestrzenianiu się nacjonalizmu (S. Amsterdamski, Trans.). Znak.

Bezłuda, J. (1934). Jóźko żołnierzem polskim. Pomorska Spółka Wydawnicza.

Bohun, M. (2006). Oblicza obsesji - negatywny obraz Rosji w myśli polskiej. In A. de Lazari (Ed.), Katalog wzajemnych uprzedzeń Polaków i Rosjan (pp. 203-302). Polski Instytut Spraw Międzynarodowych. 
Burszta, W. J. (2004). Antropologia i literatura. In W. J. Burszta, Różnorodność i tożsamość: Antropologia jako kulturowa refleksyjność, pp. 177-190. Wydawnictwo Poznańskie.

Czaplicka, J. (Ed.). (2000). Lviv: A city in the crosscurrents of culture [Special issue]. Harvard Ukrainian Studies, 24.

Czubaj, M. (2010). Etnolog w mieście grzechu. Oficynka.

Gellner, E. (2009). Narody i nacjonalizm (T. Hołówka, Trans.). Difin.

IAtsenko, P. (2010). L'vivs'ka saha. Piramida.

Kajtoch, W. (2015). Jak badać literaturę popularną? Kolejna odpowiedź. In J. Lichański, W. Kajtoch, \& B. Trocha, Literatura i kultura popularna: Metody: Propozycje i dyskusje, pp. 43-74. Pracownia Literatury i Kultury Popularnej oraz Nowych Mediów.

Kłoskowska, A. (2005). Kultury narodowe u korzeni, PWN.

Kokotiukha, A. (2015). Advokat z Lychakivs'koï. Folio.

Kokotiukha, A. (2016). Kokhanka z Ploshchi Rynok. Folio.

Kotyńska, K. (2015). Lwów: O odczytywaniu miasta na nowo. Międzynarodowe Centrum Kultury. Kotyns'ka, K. (2020). Rosiiany i rosiǐs'komovni u L'vovi: Susidy, vytisneni z polia zoru. In A. Achilli, S. Yekelchyk, \& D. Yesypenko (Eds.), Cossacks in Jamaica, Ukraine at the antipodes: Essays in honor of Marko Pavlyshyn (pp. 656-671). Academic Studies Press.

Krajewska, A. M. (2009). Trzy legendy: Walka o niepodległość i granice w polskiej międzywojennej literaturze młodzieżowej. Biblioteka Narodowa.

L'viv pislia rosiǐs'koho vtorhnennia: Rozpovid' ochevydtsia (veresen'-hruden' 1914) (N. Ryms'ka, Trans.). (2003). İ. http://www.ji.lviv.ua/n29texts/anonim.htm

Nadolna-Tłuczykont, M. (2013). Powrót książek "zakazanych" do współczesnych odbiorców (wybrane zagadnienia). Wydawnictwo Uniwersytetu Śląskiego.

Ostrowska, B. (1988). Bohaterski miś, czyli przygody pluszowego niedźwiadka na wojnie: Dla dzieci od lat 10 do 100. Wolne Lektury. https://wolnelektury.pl/katalog/lektura/ostrowskabohaterski-mis.html

Reeves, S. R., \& Wallace, D. (2015). The combatant status of the "little green men" and other participants in the Ukraine conflict. International Law Studies, 91, 361-401.

Riabczuk, M. (2004). Dwie Ukrainy (M. Dyhas, E. Gołąb-Nowakowska, K. Kotyńska, W. Stanisławski, I. Werestiuk, \& W. Witwicki, Trans.). Kolegium Europy Wschodniej im. Jana Nowaka-Jeziorańskiego.

Riabczuk, M. (2015). Ukraina: Syndrom postkolonialny (K. Golimowska, K. Kotyńska, A. Matusiak, A. Saweneć, \& M. Sokal, Trans.). Kolegium Europy Wschodniej im. Jana Nowaka-Jeziorańskiego.

Szwarc, A. (1990). Od Wielopolskiego do Stronnictwa Polityki Realnej: Zwolennicy ugody z Rosja, ich poglądy i próby działalności politycznej (1864-1905). Wydział Historyczny Uniwersytetu Warszawskiego.

Vozniak, T. (2009). Fenomen mista. ï.

Wierzejska, J. (2016). Walki polsko-ukraińskie o Lwów w literaturze dla dzieci i młodzieży dwudziestolecia międzywojennego. Bibliotekarz Podlaski, 33(2), 97-118. 
Zakrzewska, H. (1990). Białe róże: Powieść dla młodzieży z czasów inwazji bolszewickiej. Wydawnictwo Pegaz.

Zakrzewska, H. (2004). Dzieci Lwowa. Polskie Wydawnictwo Encyklopedyczne.

\title{
Kształtowanie obrazu Innego. Literacki obraz Rosjan w habsburskim Lwowie
}

\begin{abstract}
Abstrakt
W popularnym obrazie wielokulturowego Lwowa, zarówno polskim, jak i ukraińskim, do grona prawdziwych mieszkańców miasta zasadniczo nie mogą zostać zaliczeni Rosjanie. Głównym celem artykułu jest analiza nielicznych przykładów ich wizerunków w tekstach literackich dotyczących okresu I wojny światowej. Porównuję polskie strategie traktowania Rosjan jako „Innych" - barbarzyńców i wrogów, realizowane w literaturze dla młodych czytelników lat dwudziestych XX wieku, z ukraińską tendencją do tworzenia bardziej zniuansowanego obrazu w literaturze masowej ostatniej dekady. W analizie sposobów wykluczania Rosjan w tych dwóch grupach tekstów literackich uwzględnione zostają kwestie geopolityczne i problem tożsamości narodowej.

Słowa kluczowe: Lwów; Lviv; stereotyp; kształtowanie obrazu Innego; literatura ukraińska; literatura polska
\end{abstract}

\section{Citation}

Kotyńska, K. (2021). Ways of othering: Literary image of Russians in Habsburg Lviv. Sprawy Narodowościowe: Seria nowa, 2021(53), Article 2570. https://doi.org/10.11649/sn.2570 